Hönich Henrik - Koi Gyula - Nagy Ágoston - Sáfrán József

\title{
Meglátások Schlett István: A politikai gondolkodás története Magyarországon címú monográfiájának négy kötetes legújabb kiadásáról - I. rész ${ }^{1,2}$
}

\section{Observations on the Four-Volume Latest Edition of the Monograph Entitled 'The History of Political} Thought in Hungary' by István Schlett - Part 1

\section{Összefoglalás}

Esszénk fő célja Schlett István életműve, legjelentékenyebb hatású darabja első két kötete lényegi gondolati magvának megragadása. A politikai gondolkodás története Magyarországon című monográfia négykötetes legújabb kiadása kivételes vállalkozás. Jelen tanulmány a mű multidiszciplináris irányú bemutatása. A szerzők különféle tudományterületek képviselői, úgymint történettudomány, politikatudományok, jogtudomány, közigazgatás-tudomány, irodalomtudomány, illetőleg a hadtudomány. A dolgozat első részében vizsgáljuk Schlett István

Dr. Hőnich Henrik PhD, tudományos munkatárs, NKE Eötvös József Kutatóközpont (Honich.Henrik@uni-nke.hu), NAGY ÁGOston, tudományos segédmunkatárs, NKE Eötvös József Kutatóközpont (Nagy.Agoston@uni-nke.hu), Dr. Kor Gyula PhD, tudományos főmunkatárs, NKE Államtudományi és Nemzetközi Tanulmányok Kar (Koi.Gyula@uni-nke.hu), SÁfrán JózSEF, tudományos segédmunkatárs, NKE Államtudományi és Nemzetközi Tanulmányok Kar (Safran.Jozsef@uni-nke.hu). 
tudományos pályaképét, továbbá a magyar politikai gondolkodás történetét a gentilizmus (sajátos etnikai tudat) korától 1848-ig, valamint 1848-tól 1900-ig.

Journal of Economic Literature (JEL) kódok: D72, D74, P48

Kulcsszavak: forradalmak, jogintézmények, politikai eljárások, politikai gondolkodás története

\section{Summary}

The main purpose of our essay is to grasp the essential (philosophical) core of the first and second volumes of the most influential piece of István Schlett's work. The four-volume latest edition of this monograph entitled „The History of Political Thought in Hungary” is an exceptional project. This study presents the monograph in a multidisciplinary way. The authors are representatives of different fields of science, including history, political studies, legal studies, administrative sciences, literary studies, and military studies. In the first part of our writing, we pay attention to István Schlett's scientific career and the history of Hungarian political thought from the age of the so-called gentilismus (special ethnic identity) to 1848, as well as from 1848 to 1900 .

Journal of Economic Literature (JEL) codes: D72, D74, P48

Keywords: revolutions, legal institutions, political processes, history of political thought

\section{SGhlett IstVÁN PÁlyakéPe}

Schlett István az ELTE ÁJK Politikatudományi Intézete professor emeritusa, a politikatudományok ismert és elismert kutatója és oktatója. Életművének legkiemelkedőbb darabja, a legutóbb 2018-ban a Századvég Kiadónál napvilágot látott, előző kiadásait és lenyomatait (1996-1999, 2004, 2009-2010) tovább cizelláló opus, immár négy kötetben teljes. A kiadvány három számozott kötetet, illetve a számot nem viselő Appendix címmel ellátott függelékkötetet foglalja magában. A 2018-as új, részben módosított és kiegészített kiadás (Schlett, 2018a, 2018b, 2018c, 2018d) első kötete 654, második kötete 831, harmadik kötete 633, negyedik kötete pedig 419 oldal, a mű összterjedelme önmagában impozáns: 2537 oldal.

Schlett István 1939. január 2-án született Szilágynagyfaluban (jelenleg Nușfalău néven található Szilágy megyében, Románia területén). 1944-ben szüleivel magyar államterületre menekült, közelebbről Békéscsabára. Ifjúkori forradalmi tevékenységéért az ötvenes években retorzió érte. A békéscsabai gimnáziumban az érettségi vizsga évében a Forradalmi Diákbizottság tagja volt, gyűlésezésekben vett részt, illetve a lyukas nemzeti lobogó kitűzését is végrehajtotta a csoportosulás, valamint tudott egy gimnáziumi társa fegyverrejtegetési akciójáról. A fiatal Schlett egy évet töltött letartóztatásban, illetve a közügyek gyakorlásától eltiltották. Így a gimnáziumi érettségi vizsga helyett autóvillamossági szerelőként szerzett szakmunkás bizonyítványt. A fenti események miatt, a joghátrányoktól történő mentesítést követően vették 
Hönich Henrik - Koi Gyula - Nagy Ágoston - Sáfrán József: Meglátások Schlett István: ...

fel az ELTE BTK történelem-tudományos szocializmus szakára 1961-ben. A felvételi bizottságban a tudományos szocializmus szakra történő jelentkezés részben megdöbbenést keltett, részben a jelölt szakirodalom-ismerete és érvelési képességei meggyőzőek voltak, a tudományos szocializmust később Schlett számára oktató szaktanár, egyben bölcsészkari párttitkár is felvétele mellett érvelt (Bihari, 1999:7).

A sikeres felvételi vizsgát követően mindkét szakon kitüntetéssel szerzett diplomát (Bihari, 1999:7-8). A vele készült interjúban szellemi arcélét illetően jelentős adalék, hogy 1963-ban a tudományos diákköri mozgalomban egy egyetemi barátjával, hallgatótársával közösen I. helyezést értek el az első kiadásban 1931-ben, második kiadásban 1936-ban megjelent Kemse község életét feldolgozó, Teleki Pál védnökségéhez kötődő Elsüllyedt falu a Dunántúlon című könyv (Elek et al., 1936) szociográfiai kísérletének folytatásával. Szakdolgozatát 1966-ban Szabó Zoltán és a „szellemi honvédelem” címmel írta, tehát ez esetben is egy szociográfus, falukutató író volt a téma inspiráló forrása, aki a szellemi honvédelmet a nemzetiszocialista és nyilaskeresztes eszmék ellen hirdette meg. Diplomája megszerzését követően a Fővárosi Szabó Ervin Könyvtár Központi Könyvtárában dolgozott, ahol tovább mélyítette szakirodalmi ismereteit az inspiráló szellemi környezetben (Rácz, 2019:1). Innen hívta meg a Tudományos Szocializmus Tanszékre 1969-ben először óraadó oktatóként ${ }^{3}$, majd egyetemi tanársegédként az ELTE ÁJK tanszékcsoportjának akkori vezetője, Schlett korábbi oktatója, Magyar György (Bihari, 1999:8; Rácz, 2019:1-2). Schlettet 1973-ban kinevezték egyetemi adjunktussá. A „munkáskérdés” és a szocializmus a magyar politikai gondolkodásban 1848-1906 címmel védte meg 1979-ben kandidátusi értekezését, mely 1987-ben könyvformában is napvilágot látott (Schlett, 1987). Az 1979-es tudományos fokozatszerzést követően 1982-1983 között kitérőként a MAFILM Társulás Filmstúdióját vezette. Ezt követően 1984-ben tért vissza az egyetem falai közé a Politológia Csoport docenseként (Rácz, 2019:2-3). Az 1990 és 1992 közötti időszakban tudományos körutat tett elcsatolt területeinken élő magyarjainkhoz: Felvidékre, Kárpátaljára, Erdélybe és a Partiumba, Délvidékre (Bácska-Bánát/Bánság/szerb nevén: Vajdaság/, Szerémség, Muravidék), illetve az Örvidékre (osztrák nevén: Burgenland) - felkeresve e területeket (vö.: - Kárpátalját kivéve - zömmel utódállamokra utaló terület - megnevezésekkel: Bihari, 1999:9). Megjegyzendő, rendkívül sajnálatos az a jelenség, mely szerint az utóbbi évtizedekben elterjedt hazánkban a Vajdaság és a Burgenland elnevezés (továbbá osztrák uralom alatt álló településeinknek sokan csak a német nyelvű elnevezéseit ismerik, mi több, használják). Egyébiránt a Kárpátalja elnevezés sem magyar találmány. A magyar kisebbségeknél tett utazását külön kötetben foglalta össze (Schlett, 1993). Schlett Istvánt a köztársasági elnök 1994-ben egyetemi tanárrá nevezte ki. Ezt követően 2009-ben lett az ELTE professor emeritusa, aki az oktatástól 2019-ben vonult vissza (Rácz, 2019:3). Számos díj és kitüntetés birtokosa: Károlyi Mihály-díj I. fokozat (1972), Bibó-díj (1996), Apáczai-Gsere János-díj (2006), a Magyar Érdemrend Középkeresztje (2012), Széchenyi-díj (2014). Schlett egy vele készült másik beszélgetésben rámutat, hogy a politikai gondolkodás egy adott tevékenységtípushoz, a politikához kapcsolódó gondolkodási forma, melyet a külső szemlélők hajlamosak (túl)misztifikálni. Mindez egyben azt is jelenti, hogy a politikai cselekvést szükségképpen megelőzi a gondolkodási folyamat - mutat rá Schlett István (Horváth, 2018:1). Célszerűnek látszik előrebocsátani, hogy a Schlett István-i életmű számos alkotásának felvillantására dolgozatunk 
második részében, főként az appendix kötet elemzésekor kerül sor. Amennyiben Schlett István által idézett olyan eredeti forrásra hivatkozik tanulmányunk, amely korabeli ortográfiával lett felvéve, ezen textusokat a mai helyesíráshoz alkalmaztuk a jobb olvashatóság érdekében.

A hazai politikai gondolkodás a gentilizmus korától 1848-ig

Schlett István hosszú ideig sajnálatosan befejezetlen magyar politikai gondolkodástörténeti projektuma a Századvég Kiadó igényes edíciója által (három vaskos kötet és az Appendix címet viselő negyedik rész) végre valóban átfogó, egyúttal minden hasonló kísérlethez képest viszonyítva is monumentális narratívává kerekedett. Mivel jelen kétrészes tanulmány, s azon belül maga az első kötettel foglalkozó jelen fejezet is a bírált kiadvány terjedelméhez mérten többszerzős vállalkozás, ezért két dolgot már az elején szükséges leszögezni. Egyrészt e fejezet kritikai megállapításai alapvetően az új kiadás első kötetében kifejtett narratívára és ennek szemléleti hátterére vonatkoznak, és csak esetenként utalnak a függelékkötetre. Másrészt éppen az első kötet az, amely csak minimális változtatásokkal, immáron a sokadik alkalommal jelenik meg.

Legutoljára 2009-ben épp a Századvég Kiadó publikált két kötetet, melyek a jelen kiadás első és második kötetével azonos szövegűek. A folytatás azonban elmaradt, s nyilván több, mint tíz évvel később már nem is feltétlenül lett volna érdemes ugyanabban a formátumban kiadni a valóban újdonságot képviselő harmadik kötetet és az Appendixet.

A tanulmány tárgyát képező szöveg először 1996-ban és 1999-ben (Schlett, 1996; Schlett, 1999), majd 2004-ben (Schlett, 2004), illetőleg 2009-2010 között (Schlett, 2009; Schlett, 2010) jelent meg. Az első kiadás megjelenése óta idestova tehát negyed évszázad telt el. A munkának az a része, mely a magyar politikai gondolkodás történetét 1848-ig tárgyalja, azóta már megtalálta a helyét az egyetemi oktatásban és a tudományosságban is, recenziók íródtak a különféle kiadásairól. Önmagában tehát esetleg furcsának hathat egy először 25 évvel ezelőtt megjelent, s ezt követően lényegében többször változatlanul utánnyomott történeti-politológiai munkát, s az ebben kifejtett narratívát ismételten bemutatni. Az új, teljes kiadás, benne a korábban már publikált szövegrészekkel azonban kiváló apropó arra, hogy immár a mű egésze reflexió tárgyává váljon, valamint a korábban már lényegében változatlanul kiadott kötetek, illetve az újdonságot jelentő harmadik kötet és az Appendix közötti viszony is bemutatásra kerüljön. A mostani kiadást tisztán önmagában tekintve a vállalkozás egyik komoly problémája, hogy a most külön függelékkötetben közölt, nyilvánvalóan már az esetenként évtizedekkel korábban leírtakra reflektálva született fejtegetések nem épültek bele szervesen a narratíva gerincét adó első három kötetbe, másrészt viszont több esetben pusztán szó szerint megismétlik a korábbi kötetekben foglalt módszertani megállapításokat. Úgy véljük, az új sorozat akkor jelentett volna valódi nóvumot, ha a szerző a változatlan utánnyomás és az ahhoz csatolt függelék publikálásának nézetünk szerint elhibázott koncepciója helyett beépítette volna nemcsak a saját, az Appendixben megfogalmazott reflexióit az elbeszélésébe, de számolt volna az időközben megjelent szakmai reakciókkal, továbbá az első kiadás óta megjelent, friss teoretikus és empirikus eszmetörténeti, illetve tágabb történettudományi és irodalomtörténeti szakirodalommal. Ebben a formában nemcsak annak a kornak a monumentumává merevedett az 
ismételten kiadott első kötet, melyben keletkezett, de az is nyilvánvaló, hogy a „politikai gondolkodás történetének" schletti megközelítése már a narratíva megformálódása idején, a kilencvenes években is problematikusnak számított, úgy teoretikus alapjait, mint a felhasznált forrásanyagot tekintve. Jelen tanulmány egyik szerzője már 2012-ben jelezte a kötetekben érvényesülő megközelítés, s mindenekelőtt a „paradigma” Schlett-féle fogalmának problémáit és komoly korlátait (Nagy, 2012). Az akkor megfogalmazott kritika az újonnan elkészült kötetekkel kapcsolatban sem vesztette érvényét, a harmadik kötet ugyanis lényegében továbbra is a 19. században megjelenő modern politikai ideológiákból fakadó értelmezési igényhez hozzáigazított korábbi szemléleti alapokon épül fel. Az Appendix is inkább csak differenciálja, de lényegi pontokon továbbra sem korrigálja azokat az eredeti megközelítésből fakadó teoretikus problémákat, melyek a szemléleti-módszertani keret többé-kevésbé következetes érvényesítése következtében sajátos korlátok közé kényszerítik a történeti elbeszélést, egyúttal rugalmatlansága és lezártsága miatt elzárják azt mind a tudományos fősodortól, mind a széles értelemben vett politikai kultúrával és politikai eszmetörténettel foglalkozó innovatív megközelítésektől.

Miként a mű egészét, az államalapítástól 1848-ig terjedő időszak politikai gondolkodásának történetét összefoglaló első kötet elemzéseit is a szerző által kontextualistaként definiált szemléletmód határozza meg. A bevezetésben foglalt elméleti-módszertani alapvetés szerint a politikai gyakorlat és az ennek függvényeként felfogott politikai gondolkodás mindenkori kontextusa két fő alkotóelemből áll össze. Ezek egyike a politikai tér, amely a schletti megközelítés szerint azt a ,sajátosan strukturált társadalmi-politikai közeget” jelenti, „amelyben a politikusok cselekednek" (Schlett, 2018a:42). A politikai tér tehát lényegében azon társadalmi-politikai keretrendszerrel, illetve szituációval egyenértékű, amely a cselekvő politikust az adott pillanatban körülveszi. Ide tartozik egyrészt minden, a „politika előtti világhoz” tartozó tényező a gazdálkodás módjától kezdve a társadalmi tagoltságon és a demográfiai helyzeten át a kulturális viszonyokkal bezárólag, másrészt a „politika világához” sorolható faktorok is, mint például a politikai berendezkedés, a politikai szerepek, az intézmények vagy akár a normák. A kontextuális keretek másik komponense a paradigma. Mint kiderül, alatta „egy zárt politikai és gondolati rendszer” értendo, amely „magába foglal egy sajátos politikai berendezkedést, beleértve az intézményeket, normákat, politikusi szerepeket, illetve meghatározott előfeltevéseket, értékelési és értelmezési mechanizmusokat, ismereteket, gondolkodás- és beszédmódokat, szerepfelfogásokat" (Schlett, 2018a:43).

A bevezetőben foglaltak értelmezése elé akadályokat gördít, hogy a két módszertani főfogalom fenti, meglehetősen általános definíciója nehezen teszi megragadhatóvá az általuk leírni hivatott jelenségek körét: a „politikai tér” és a „paradigma” alá sorolt részterületek jól látható tartalmi heterogenitásából egyfajta bizonytalanság adódik. Az olvasó ezen benyomását tovább erősíti, hogy a politikai gondolkodást meghatározó, a mindenkori kontextust alkotó két fő dimenzió bizonyos - nem csekély - átfedést mutat egymással, hiszen mind a „politikai tér”, mind a „paradigma” definíciójában integráns szerepet töltenek be egyrészt a politika világának olyan strukturális elemei, mint az intézmények, másrészt viszont olyan, leginkább a politikai kultúra alá sorolható komponensek is, mint a politikusi szerepek vagy a normák. Jól látható tehát, hogy a két terület precíz elválasztására nem kerül sor, ugyanakkor nem egészen világos, miért van szükség a két terminus éles fogalmi megkülönböztetésére akkor, ha 
a tényleges meghatározás során kiderül, valójában egymással kontinuus, jelentős átfedéseket mutató jelenségköröket jelölnek. A zavart csak növeli, hogy a vonatkozó eszmefuttatásokban erre való reflexiót nem találunk, így marad némi kétely a tekintetben, hogy egyáltalán tudatos manőverről van-e szó.

A szerző a paradigma fogalmához - Thomas Kuhn klasszikus tudománytörténeti munkáját követve - a zártság és a diszkontinuitás képzeteit köti. Miként a paradigma mibenlétét taglaló fejezet egy helyén fogalmaz, „...létezik [...] egy széleskörűen elfogadott «kódrendszer», értelmezési keret: a kor sajátos problematikája, szemlélete, értékrendje, fogalmi rendszere, nyelvezete, amelyen belül a politikai diskurzusok zajlanak. A «rendiség paradigmáján» belül másról és másként gondolkodnak és beszélnek a politikusok, mint a «liberális paradigmán» belül, ám az egyes paradigmákon belül nagyjából azonos jelentésük van a fogalmaknak, hogy úgy mondjuk, azonos nyelven beszélnek az ellenfelek is".

Vagy máshol: „[A] vonatkozási és értelmezési rendszerek, gondolati struktúrák összeegyeztethetetlenek; itt is csak választás lehetséges, a paradigmák közötti választás. [...] [A] paradigmák között a süketek párbeszéde zajlik” (Schlett, 2018a:44).

A paradigmák ilyetén, homogén képletekként történő leírása meglehetősen problematikussá teszi az azokon belüli nézet- és érvrendszerek nyelvi-diszkurzív szinten történő differenciálását, az egyes paradigmák keretei között érvényre jutó különböző fogalomhasználatok, képzet- és értéktársítások árnyalt megkülönböztetését, illetve annak megragadását, hogy ezek hogyan viszonyul(hat)nak egymáshoz, illetve milyen interakciókba kerül(het)nek egymással a politikai viták során. Ami pedig ennél is súlyosabb problémát jelent egy alapvetően történeti megközelítést alkalmazó, illetve történeti tárgyú munka esetében, az az, hogy mindezen problémák nem csak szinkrón, hanem diakrón szinten is érvényesülnek. E módszertani keret egyik vakfoltja ugyanis a fogalomtörténeti perspektíva, amely gyakorlatilag teljes mértékben zárójelbe kerül, hiszen a paradigma zárt rendszerként való felfogására építő modell alapvetően érzéketlen a szemantikai mozgások történeti aspektusaira. Csupán egyetlen példát említve a sok közül: a rendi-nemesi gondolkodáson belül a 18. század végétől kezdve találunk arra utaló jeleket, hogy az „alkotmány” fogalmát a politikai szereplők a rendi-nemesi szabadságok összességét jelölő kifejezésként kezdték értelmezni; ez a terminus tehát csak ekkoriban kezdte felvenni azt a jelentéskört, amely aztán a 19. századi rendi sérelmi politika egyik kulcsfogalmává tette. A történeti forrásanyag alapján igen nehezen (sőt sehogyan sem) lehetne amellett érvelni, hogy a „rendi paradigma” szerző által is több évszázadosnak tételezett története során e fogalom (illetve latin megfelelője, a constitutio) alatt mindvégig ugyanazt értették volna a politikai szereplők. Mivel a politika nagyrészt a nyelvi közegben zajlik, illetve a nyelv médiumán keresztül nyer formát, a hasonló, fogalmi és diszkurzív szintű folyamatok a politikai gondolkodás történetének nem megkerülhető dimenzióját képezik - a „paradigma” kategóriájának az elemzői eszköztár központi terminusává avatása, főként pedig annak a fenti értelemben vett, homogén, zárt és konstans képletként való felfogása azonban szinte lehetetlenné teszi a fogalomtörténeti perspektíva szükséges mértékben történő figyelembevételét az értelmezői oldalon. ${ }^{4}$

A szerző által felvázolt modell emellett a paradigmák közti váltások elbeszélését is megnehezíti. Vagyis annak leírását, hogy miként válnak érvénytelenné a korábban domináns po- 
zícióban lévő paradigmák és miképpen kerülnek a helyükbe újak. Kérdéses ugyanis, hogy egyáltalán hogyan kerül sor a politikának és a politikai gondolkodásnak a „paradigma” fogalma alá sorolt, egymástól szinte hermetikusan elválasztott makroszintű egységei közti átalakulások, átmenetek folyamataira, ha abból indulunk ki, hogy a politikai gondolkodás története a fenti, kifejezetten merev kereteken belül zajlik. E kérdéskör központi jelentőségét érzékelve a szerző külön alfejezetet szentel a problémának, amelyben továbbra is a kuhni modellt, mint mintát alkalmazva amellett érvel, hogy a politikai berendezkedést érintő, illetve a politikai gondolkodásban lezajló paradigmaváltásokat a tudományos forradalmak analógiájára kell elképzelnünk. Mint egy helyütt fogalmaz, „... a léthelyzetekben, érdekviszonyokban, az intézményekben, a világszemléletben, az értékrendben, a konfliktusok jellegében és megközelítési módjában bekövetkező egy ponton a politikai gondolkodás szempontjainak és témáinak, fogalmi készletének, szóhasználatának, nyelvi eszközeinek radikális megváltozását eredményezik. [...] E fordulat a paradigmaváltás" (Schlett, 2018a:44).

Arra az óhatatlanul felmerülő kérdésre azonban, hogy vajon miképpen mehet végbe egy ilyen radikális változás egyik pillanatról a másikra és mi módon eredményezheti az „előző” paradigmával lényegében diszkontinuus „új” paradigma megszületését, nem kapunk választ.

A bevezető fejezetben felvázolt paradigmamodell kapcsán mindazonáltal azt is hangsúlyozni szeretnénk, hogy nem gondoljuk, hogy ne lehetne érvelni amellett, hogy a politikai gondolkodásnak létezik egy olyan makroszintű léptéke, melynek belső viszonyai leírására alkalmas lehet a „paradigma” szerző által ajánlott értelmezői kategóriája. Amit azonban túlzónak és torzító hatásúnak tartunk, az ennek kizárólagossá tétele és a paradigmának mint a politikai gondolkodás története egészét meghatározó általános, korokon átívelő strukturális állandónak a tételezése.

A 2018-as összkiadás során először megjelent Appendixben a szerző összesen nyolc paradigmát különböztet meg egymástól az európai és ezen belül a magyar politikai gondolkodás történetében. A (1) gentilizmus, a (2) kora keresztény állammisztika (máshol: kora keresztény patrimoniális állam), a (3) (csonka) hủbériség, a (4) rendiség (máshol: rendi dualizmus), az (5) abszolutizmus, a (6) liberalizmus, a (7) szocializmus és a (8) konzervativizmus (Schlett, 2018d) közül az első kötetben tárgyalt időszak tekintetében az első öt paradigma bír relevanciával. Figyelmet érdemel ugyanakkor, hogy az első kötet elemzései és az Appendixben található fenti felsorolás nem teljesen egyezik, hiszen a gentilizmus csak az utóbbi esetben tűnik fel önálló paradigmaként. Ennek megfelelően az első kötet bevezetőjében azt találjuk, hogy az abban tárgyalt mintegy nyolc és fél évszázad politikai gondolkodásának történetében „legalább négy paradigma különíthető el”, hiszen ,,a kora keresztény patrimoniális állam, a (csonka) hűbériség, a rendi dualizmus, az abszolutizmus nemcsak az intézmények szintjén különböznek egymástól, hanem a gondolati struktúrákban is" (Schlett 2018a:45). Bár ezen ellentmondás explicit feloldása az első kötet vonatkozó részeiben nem történik meg, ez nem különösebben meglepő, hiszen a gentilizmust és annak „eszmei alapzatát jelentő barbár etnikai tudatot” a szerző - a középkori politikai gondolkodást feldolgozó részek csaknem egészéhez hasonlóan itt is Szűcs Jenő kutatásaira támaszkodva - az államalapítás előtti időszak meghatározó „gondolati modelljeként” kezeli. E modell ugyan hatott később is - mint Szűcs nyomán megtudjuk, utolsó nyílt manifesztációinak a pogánylázadások tekinthetők -, az ezredforduló után 
nyilvánvalóan elvesztette domináns szerepét.

Az elemzések során mindazonáltal az is kiderül, hogy a fenti felsorolás más elemeiről is elmondható, hogy nem teljesen egynemű jelenségeket jelölő, illetve nem azonos kategoriális szinten elhelyezhető fogalmakról van szó. Az aránytalanság már pusztán mennyiségi szempontból is szembetűnő: míg a liberalizmus első, mozgalmi szakaszát csak az első kötet több mint háromszáz oldal terjedelemben tárgyalja - nem beszélve a következőről, amelynek csaknem egészét a liberalizmus 1848 utáni története bemutatásának szenteli a szerző - a kora keresztény állammisztikával foglalkozó fejezet mindösszesen hét, a (csonka) hủbériséget tárgyaló fejezet pedig nem több mint négy oldal hosszú. Valamivel jobb a helyzet az egymással vetélkedő paradigmákként bemutatott rendiség és abszolutizmus esetében. Azonban jelentőségük és hosszútávú hatásuk figyelembevételével még a nekik szentelt mintegy kétszázötven oldal is aránytalanul kevésnek tűnik a liberális paradigmát leíró, több mint ezer oldal terjedelmű, az első két kötet túlnyomó hányadát elfoglaló részekhez képest. E szélsőséges terjedelmi kilengések tartalmi szempontokkal semmiképp sem indokolhatók, főképp akkor nem, ha komolyan vesszük, hogy a nyolc paradigma esetében azonos kategoriális szinten elhelyezhető, egymással legalábbis összemérhető súlyú és jelentőségű jelenségekről van szó. Nem kétséges, hogy mindez persze részben a szerző sajátos érdeklődésének és kutatási preferenciáinak is betudható, ám sejtésünk szerint ezen aránytalanságok egyben a paradigmamodell buktatóit is példázzák - nevezetesen azt, hogy milyen problémákhoz vezethet, ha egy közel ezer éves történet változatos és ellentmondásos, egyszerre sok szinten zajló valóságát néhány strukturális alaptényezőre redukálva kíséreljük meg leírni.

E sejtés tartalmi szempontból is megerősítést nyer, hiszen a szöveget olvasva nyilvánvalóvá válik, hogy a fenti felsorolás egyes elemei nem csak, hogy nem azonos súllyal esnek latba az elemzések során, de az is felvethető, hogy közülük a szerző nem mindet kezeli a többivel „egyenrangú”, teljes értékű paradigmaként. Emellett pedig a politika és a politikai gondolkodás történetének olyan további „egységeit” is detektálja, amelyek valamilyen oknál fogva nem elégítik ki a „paradigmaságnak” az értelmező történész által felállított kritériumait, illetve olyanokat is felfedez, melyek megrekedtek a paradigmává válás útján. Ami az utóbbi változatot illeti, mindenekelőtt a konzervativizmus tekintetében fogalmazódnak meg kérdőjelek a szerző részéről, amennyiben komolyan elgondolkodik arról, hogy vajon a konzervativizmus ténylegesen paradigmává vált-e. A hűbériség magyarországi változata szintén kilóg a sorból, hiszen az (egyébiránt alapvetően összhangban a magyar középkorkutatás eredményeivel) mint „csonka hűbériség” kerül bemutatásra, tekintettel arra, hogy a „tiszta hűbéri szerkezet [...] integrálhatatlan volt a 13. századi magyar társadalomba” (Schlett, 2018a:76). Ezt és az említett szélsőséges terjedelmi eltéréseket figyelembe véve kérdés, hogy mi indokolja a hủbériségnek például a liberalizmussal vagy akár a rendiséggel való egy szinten történő kezelését.

Tovább bonyolítja a helyzetet, hogy Schlett István munkájában az 1526 előtti rendiség, illetve rendi dualizmus paradigmájának fo tendenciája mellett „mellékáramlatokat” is megkülönböztet, illetve a 18. század második felében teret nyerő felvilágosult politika esetében az „álparadigma” fogalmát is bevezeti. Ami az előbbieket illeti - ebben az esetben is Szűcs Jenőt követve - ilyenként tartja számon a humanizmust és a spiritualizmust, melyeket azonban kizár a politikai gondolkodás köréből. Mint leszögezi, e „szellemi áramlatok” nem tekinthetők 
Hönich Henrik - Koi Gyula - Nagy Ágoston - Sáfrán fózsef: Meglátások Schlett István: ...

a politikai gondolkodás paradigmáinak, hiszen „egyik sem a politika szférájára vonatkozik; képviselőiket a politikán kívüli szempontok vezérlik." Hogy mégis említést érdemelnek a politikai gondolkodás történetét tárgyaló munkában, azt az indokolja, hogy egyrészt befolyásolták azt, új elemekkel kiegészítve ,a fó áramlat, a rendi «nacionalizmus» érvelési módját”, másrészt „néhány ponton a rendi társadalom- és politikaszemlélet kritikájához adtak elméleti és morális alapot" (Schlett, 2018a:138). E sorokat olvasva ugyanakkor felmerül a kérdés, hogy vajon mi lehet az oka annak, hogy hasonló, paradigmának ugyan nem minősíthető, de a politika szféráját befolyásoló „mellékáramlatok” megkülönböztetésére a kötetben máshol nem kerül sor. Amennyiben ugyanis a magyar politikai gondolkodás történetét a Schlett István által javasolt modell alapján kívánjuk elbeszélni, felvethető, hogy ilyen, nem kifejezetten politikai, ám a politikai gondolkodást befolyásoló áramlatok más korszakok vonatkozásában is detektálhatók volnának.

Más minőséget képvisel az álparadigma fogalma, amely a felvilágosult politika rendi, abszolutisztikus és radikális irányainak minősítésére kerül bevezetésre a kötetben. A felvilágosodás és ennek magyarországi ,átpolitizált” verziói, a felvilágosult rendiség, a felvilágosult abszolutizmus és a legradikálisabb változat, a magyar jakobinusok mozgalma ugyanis a szerző szerint bár látszólag paradigmatikus érvénnyel határozták meg a 18. század második felének politikai viszonyait, valójában nem tekinthetők paradigmáknak. Ennek oka, hogy ténylegesen nem rendezték át a (hazai) rendiség és az (idegen) abszolutizmus ekkor már több évszázada meghatározó szembenállását: „A felvilágosult politika gondolati struktúráján belül maradva nem létezett megoldás a felvetődött dilemmákra.” Mint a szerző sommásan megállapítja, a nevezett irányzatok válaszai politikai értelemben terméketlennek bizonyultak, amit az is jól mutat, hogy a magyar jakobinus mozgalom bukása utáni évtizedekben az abszolutizmus és a rendiség egymással konfrontálódó paradigmáiról mintegy „lehámlott a felvilágosodás frazeológiája és helyükbe a régi érvelés lépett. Az udvar részéről a királyi hatalom korlátlanságának tétele adta az alapot, kiegészülve a magyarok «vadságának», «barbárságának» régi toposzaival. A nemesség részéről pedig a rendi alkotmány védelme, kiegészülve a rendi nacionalizmussal" (Schlett, 2018a:315). Nem kétséges, hogy a magyar rendiség és a bécsi központi kormányzat szembenállása a politika egészét meghatározó alapvető faktora az időszaknak, ám ennek fenti leírása arra is rávilágít, hogy milyen veszélyeket rejt magában, ha történeti jelenségek leírásakor bizonyos deduktív, magyarázó segédfogalmaknak (jelen esetben a paradigma terminusának) túlságos jelentőséget tulajdonítunk. Erre annak jelzésével világíthatunk rá, hogy a felvilágosult politika irányzatainak a „termékenység" /"terméketlenség” ellentétpárja mentén történő megítélése igencsak perspektívafüggő: felvethető ugyanis, hogy amennyiben ezt nem a rendiség és abszolutizmus „paradigmaságának” mércéjével mérjük, egészen más eredményre juthatunk. A hasonló, „fejnehéz”, deduktív modellek alkalmazásával a történész azt a kockázatot vállalja, hogy túlságosan elvont értelmező terminusaihoz ragaszkodva adott esetben a kelleténél nagyobb mértékben redukálja a múlt összetett, ellentmondásos jelenségeit az adott elméleti kereten belül érvényesnek tekintett belső törvényszerüségeknek megfelelően. 


\section{A Hazai POLITIKAI GONDOLKOdÁs AZ \\ 1848-AS FORRADALOMTÓL 1900 -IG}

Schlett István A politikai gondolkodás története Magyarországon 2. című műve (Schlett, 2018b) közvetlen folytatása az első kötetnek (Schlett, 2018a), amely az államalapítástól 1848-ig mutatja be és elemezi a hazai politikai gondolkodás történetét. A második könyv céljai ugyanazok, mint az elsőnek: először is bemutatni a politikát mint saját tevékenységi formát, másodsorban az adott kor gondolkodásmódjának feltárását, miképpen hatottak rá a belső és külső tényezők, amelyek aztán gyakorlati cselekvésben öltöttek testet, ezáltal formálva történelmünket. A gondolkodás kereteit, struktúráját, szimbolikáját, paradigmaváltásait és téziseit vizsgálva eljuthatunk az adott kor politikai cselekvéseinek értelmezéséhez, ami a jelen számára is hasznos tudást szolgáltathat. Azokra a kérdésekre keresi a választ, hogy a politikai alanyok miért, miról és hogyan gondolkodnak, ami által politikai cselekvőkké válnak (Mándi, 2015:15). A politikai gondolkodás a politikai cselekvés egyik alapfunkciója, ezáltal a vizsgálatot Schlett István úgy folytatja le, hogy ezt a párost kapcsolja össze, és keresi az összefüggéseit a magyar historika kiterjedt elemzési kerete mentén. A szerző könyve azonban nem történelemkönyv (Schlett, 2018b:817), de eszmetörténeti vonásokat hordoz magán (Bodnár-Király - Nagy, 2008:186). Nem tud minden történelmi folyamatra visszahatni, hiszen annak bemutatásához könyvtárnyi írott anyag sem lenne elegendő.

A második kötet 1848-tól vezet minket végig egészen az évszázad végéig. Észrevehető, hogy jóval szűkebb időkört ölel fel a kötet, mint az előző, ami már rámutat arra, hogy a korszak gondolkodása mennyire komplex és összetett lett, ahol a politikai gyakorlatot sem szimpla döntési mechanizmusok előzték meg, valamint egyre több gondolkodásmódnak volt esélye összecsapni. De ettől függetlenül nem egyedüliek, rengeteg más körülmény is hatott a történelem folyamának alakulására, de kétségtelenül kivételesen nagy szerepe van benne. A vizsgált korszak politikai gondolkodása sokszor csupán „vergődés” a komplex körülményekre nehezen adható válaszok miatt. Mondhatni számtalan alkalommal a döntések reményteli próbálkozások voltak csupán. Egy olyan jövőbeli forgatókönyvet akartak a társadalom számára kreálni, amelyekben a köz boldogsága a leginkább maximalizálható. Ennek érdekében a döntéshozók sokszor nyúlnak ideológiákhoz, világképekhez, eszmékhez.

A politikai gondolkodás története Magyarországon 2. című kötet egy ilyen ideológiának a válságától indulva jut el annak mérsékeltté válásáig, és mutatja be a gondolkodásmód átalakulásával járó útkeresést. Ez az ideológia nem más, mint a liberalizmus, amelynek gondolkodásbéli problémái, kihívásai, átalakulásai, alkalmazkodása, céljai, válaszai és konkurenciái a kötet központi témáját adják.

A könyv a liberalizmus első válságával indít az Ötödik rész legelején. 1849 tavaszára nyilvánvalóvá vált, hogy az ideológiák sem mindenhatók, és nem nyújtják azokat a megoldásokat, amiben a politikusok oly mohón hittek. A „,népek tavasza” és a ,,világszabadság” helyett új despotizmusok jöttek létre, amelyek a liberalizmus alaptéziseit megkérdőjelezték (Schlett, 2018b:13). Az 1848-49-es forradalom és szabadságharc után a liberális önbírálat megkezdődött Magyarországon, aminek a főbb jellegzetességeit és összefüggéseit ismerhetjük meg ebben a részben. A szerző Kemény Zsigmond és Eötvös József nézeteivel indít, akik még 
Hönich Henrik - Koi Gyula - Nagy Ágoston - Sáfrán József: Meglátások Schlett István: ...

mindig ragaszkodtak a liberalizmus alapértékeihez, és a forradalom bukását inkább a radikális Kossuth Lajos elhibázott politikájának eredményének tekintették. Az említett két szerző hatását tartja Schlett a forradalom után a berendezkedés, és az azt követő gondolkodás alapköveinek, ami nem is változik meg a mű egésze folyamán. Eötvös még megfogalmazza a mozgalmi liberalizmus kritikáját, aminek bukását az eszme félreértelmezése okozta elsődlegesen. Kemény azonban már próbál a jövőbe tekinteni, és a berendezkedő liberalizmus ideológiáját tárja elénk, amire a legjobb megoldás a kormányzó liberalizmus. A politikai szándék nem más, mint a motiváció. Schlett szerint Magyarország politikai gondolkodásának mindent átható mozgatóereje a tárgyalt korszakban nem volt más, mint az útkeresés az Osztrák-Magyar Monarchián belül. A szükséges újrafogalmazás rengeteg kérdést felvetett: Nemzeti vagy semleges állam? Mi az uralkodó eszméknek a valódi értéke, értelme? Mik a nem politikai szférák korlátai? Ahogy Schlett István is rámutat és érzékeltet, a gondolkodók tudták, hogy bármilyen választ is adnak ezekre a kérdésekre, a liberalizmusnak minden tekintetben módosulnia kell. Ehhez - ami főképp Eötvös értelmezésében látható - egy erős pragmatizmus szükséges, mivel a Széchenyi-féle moralizálás sem vezetett eredményre, ugyanis túlzottan szétszakította a politikai réteget. Így az intézményi politizálás hazánkban is háttérbe szorul jó időre az abszolutista akarattal szemben, annak visszatéréséig viszont magabiztos liberális eszmékre volt szükség, ami a gyakorlatban a passzív ellenállásban öltött testet.

A második kötet második fejezete (hatodik rész) pontosan az említett átalakult ideológiákból képződő politikai gyakorlatot viszi tovább, politikai programok formájában. Az új Ausztria programja valóban forradalmi változásokat hozott Magyarországon, bár nem olyat, amilyet a szabadságharc alakjai szerettek volna. Schlett István a fejezet során végig kiemeli a liberalizmust, mint a fó vezérelvet. A konzervatívok véleménye szerint a Kossuthi konzervativizmust tovább lehet vinni, azonban ez 1860-ban, amikor az uralkodó kiadja diplomáját a magyar helyzettel kapcsolatban, teljesen különbözik a Dessewffy által benyújtott tervtől, amelyben mind a birodalom, mind Magyarország egy „egészen új és epochalis országlási rendszerben” jelenik meg (Schlett, 2018b:115). Schlett sokkal nagyobb sikernek éli meg, és ezért is elemzi hosszan a Deák Ferenc-féle passzív ellenállást, ami szerinte a kiegyezés egyik döntő kiváltó oka lett. A kiegyezés nem jöhetett volna létre a Kemény és Eötvös által lefektetett gondolkodásmód nélkül, amit aztán a Deák-párt gyakorlati politizálása során is alkalmazott. Ez annak is köszönhető, hogy a mérsékelt liberalizmus eszméje megjelent széles körű ellenállásban, ami által sok emberhez elért, és hallatni tudta saját hangját. Az egész kormányzást már áthatotta a politika, de a ,48-asság” koncepciója olyan magas szintű szellemi és ideológiai műhelyekbe is elért, ahol nem csak a politikai tanok voltak elsődlegesek. A fegyveres konszolidáció elhozta azt, hogy Magyarország különállása gyakorlatilag megszűnjön, az uralkodó lebontotta a politikai szembenállás intézményeit és szervezeteit. A Bach-rendszer eredményeképp egy erős ellenállás jött létre, azonban a kiegyezéshez vezető utat nem mindenki a liberális elvek mentén képzelte el. A polgárosodás szintén megerősítette a rendszer elutasítottságát. Attól függetlenül, hogy rendkívül nagy ellentétek törtek fel a politikai gondolkodásban, az ellenállás eszméje és a gyakorlati programok érvényre juttatása egységessé kovácsolta a normál esetben különálló eszméket is.

A könyv hetedik része a mérsékelt liberalizmus rendszerének kiépítését fejti ki az olvasó 
számára. A Bach-rendszer 1858-as végével megindulhatott a politikai diskurzus a szereplők között, és elkezdődött a nemzetállam kiépítése az Osztrák-Magyar Monarchián belül. A kiegyezést Schlett István a mérsékelt liberalizmus sikerének tekinti, mivel megvalósult a nemzeti polgárosodás eszménye, ami véleménye szerint: „, [A] nemzeti akarat teljes szabadsága a belpolitikában és paritáson alapuló befolyás a közös ügyekben.” (Schlett, 2018b:253).

Schlett egyenesen úgy véli, hogy a pártpolitikai kompromisszumokból a Deák-párt jött ki győztesen, ami egyenesen a többi ideológia és politikai program vereségét jelentette: a nemzeti radikalizmusét, az neoabszolutizmusét, a liberalizált vagy föderális egységes állam programjáét, a konzervativizmus konstitucionalizmusát (Schlett, 2018b:253). Így az 1867-es kiegyezés, mint új közjogi rendszer, a mérsékelt liberalizmus nem véletlenül hosszan taglalt tanainak gyakorlati valójában tudott létrejönni. Megváltozott az állam szuverenitása, az államszövetség a liberális alkotmányosságra épült. Deák Ferenc liberalizmusát - többször hangoztatva - a józan ész gondolkodásmódjának tartja a szerző.

Az erős konzervatív ellenzékre - élén a külhonban rekedt Kossuth Lajossal - Schlett gyakran az érzelmi politizálás mühelyeként utal, nem egy esetben kritikus hangnemben, ami a könyv felépítéséből és fókuszából is látható. Elismeri, hogy hatottak még a liberális gondolkodásra is a politikai szenvedélyek, de az érdekracionális gondolkodás, ami elengedhetetlen volt ebben a korszakban, csak a liberális politikai gondolkodásban öltött testet. A súlyos ellentétek a két politikai gondolkodásmód között az első világháborúig jelen voltak a politikai diskurzusban, sőt, Schlett István szerint egyenesen a konzervatívok előretörése miatt omlik össze a dualizmus rendszere (Schlett, 2018b: 452). De az 1848 óta jelen levő ellentét, ami fóképp Kossuth és Deák párharcában testesült meg, jól rámutat arra, hogy a politikában a racionalitás nem mindig a fő mozgatórugó, ezért vizsgálata különleges, komplex módszereket kíván. Még akkor is, ha igazából a két tábor célja ugyanaz, de a megvalósítás menete mereven eltér egymástól. Végül a harcból Deák Ferenc került ki győztesen a kiegyezési törvények elfogadásával, de az érzelmi politizálás nem hagyott alább, ami - mint említettük - Schlett szerint elvezetett a dualizmus válságához is. A kiegyezés után meglendült a gazdasági növekedés, út nyílt a polgárosodás felé, megindult a városiasodás, az oktatás színvonala növekedett. Elmondható, hogy teljesen megváltoztatta a társadalmat a liberális gondolkodás és nem csak a nemzeti szuverenitás szempontjából. Ilyen körülmények között az amúgy is népszerű Deák Ferenc könnyen tudta pragmatizmusát az érzelmi politizálással szemben érvényesíteni: , ,... sokan más úton, más eszközökkel akarják előmozdítani a haza javát, mint amelyeket én célszerűeknek és lehetőnek tartok. Hiszen ki az, aki csalhatatlannak merné magát tartani! Az eszmesurlódások az igazságot derítik ki, a mozgalom alkotmányos életünknek éltető levegője, és míg ez az alkotmányosság körében forog, csak szerencse, nem kár a nemzetre nézve. A fölzaklatott szenvedélyek azok, mik keblemet aggodalommal töltik el. A szenvedély mindenkor rossz tanácsadó, s a törvényhozás terén, hol komoly és nyugodt megfontolás szükséges, gyakran veszélyes is lehet." (Schlett, 2018b: 425).

A Deák-idézet jól szemlélteti Schlett István módszertanát és nézeteit, ami az egész könyvön végigvonul, azaz a racionális politizálás érvényességét az érzelmi politizálással szemben. Véleménye kiérezhető Deák ideológiájával egyetértésben, azaz a józan ész és a társadalmi hasznossági szemlélet előnye a szenvedélyektől túlfütött politikával szemben. A 19. század vé- 
Hönich Henrik - Koi Gyula - Nagy Ágoston - Sáfrán József: Meglátások Schlett István: ...

gén is megfigyelhető, a 20. század Kossuth-képével kapcsolatos viták kapcsán Schlett egyértelműen a Kossuthot kritizáló, gondolkodásának realizálását nélkülöző párt mellett foglal állást.

A nyolcadik rész rávilágít arra, hogy a megerősödött liberalizmus eszméje, ha nem is kerül feltétlenül válságba, képes rendülni, ha nem egyértelmű, komplex kérdésekkel találja szemben magát. Ilyen az állam és egyház viszonya, az egyéni vagy kollektív szabadság, a liberális vagy fejlesztő állam dilemmái. Ezekben a kérdésekben hozott kompromisszumokat veszi végig a szerző a fejezet során, aminek a végére arra a megállapításra jut, hogy a gyakorlati politizálásba az elvszerűség gyakran beférkőzött, ezért már nem is lehet megkülönböztetni feketén-fehéren a politikai döntéseket, hanem ,szürke,” kevert lett a metódus (Schlett, 2018b:610-626).

A liberalizmus elmúlt évszázadban és korunkban is látható ciklikussága eredményességből válságba az egész könyvön áthúzódik, „,végigrobog”. A kilencedik fejezet ismételten egy ilyen problematikus időszakba kalauzol el minket, mikor is a kiegyezés okozta örömmámor gyorsan szertefoszlik, és a liberalizmus teoretikusai és politikai végrehajtói ráeszmélnek, hogy a gyors társadalmi változásokhoz füzött remények falakba ütköznek. A nemzeti polgárosodás és a társadalmi integráció veszélybe került. Az eredmények elmaradása természetesen magával hozta a politikai pártok közötti szakadék egyre súlyosabb elmélyülését is. A fejezet maga egyben egy konzervatív (azaz a Szabadelvü Pártra és Jobboldali Ellenzékre vonatkozó) kritika is, amelyet a szerző „öndefiníciós” jelzővel illet, amiből arra következtethetünk, hogy a konzervatívok csak a liberálisokkal szemben voltak képesek meghatározni magukat, és a már említett „szürke metódus” jelent meg gondolkodásukban. Ez is okozta vesztüket: nem voltak képesek olyan alternatívát nyújtani a kormányzó liberalizmussal szemben, ami ténylegesen megkülönböztette volna őket. Apponyi gyakorlatilag egyszemélyben testesítette meg a magyar konzervativizmust, ráadásul mérsékeltből formálódott át nemzeti radikálissá, ez pedig az adott történelmi korszakban nem talált befogadásra sem a társadalom, sem a politikai szféra részéről. Schlett egyértelműen a mérsékelt liberalizmust hozza ki a korszak győztes, és egyben sikerekkel átszőtt ideológiájának, mivel véleménye szerint a történelem eldöntheti, mik voltak azok a döntések, amelyek jónak vagy rossznak számítottak. Az elemzési keret is nem véletlenül a liberalizmus volt a második kötet szűk 60 éves periódusában: minden ellenfelével szemben győzni tudott, és meghatározta a politikát. A szerző azonban antagonisztikus állításba sodródik könyve végén, amit maga is elismer: végkifejlet-magyarázó elemzési szempontból a mérsékelt liberalizmus nem tudta elérni a végső célját, hisz egy világháborúba sodródott a monarchia, megmaradtak az etnikai törésvonalak, a kulturális ellentétek egymásnak feszültek, a társadalmi osztályok egyenetlenek maradtak. A válságok ismét a tanok újragondolására késztették a teoretikusokat.

A második kötettel Schlett István a politikai gondolkodás eszmetörténi, monografikus kánonjához szolgáltatott megkerülhetetlen művet a liberalizmus irodalmi, történelmi, politikai filozófiai, politikai gondolkodásbéli aspektusából. Az eszmetörténeti leírás módszertana nála egyértelműen a liberalizmust helyezi a vizsgálatok origójába, de a teoretikus-módszertan szempontjából ez ildomos volt, mivel olyan óriási mennyiségü anyagot kellett felhasználni, amely elvezet a kutatás keretének ilyen mértékű leszűkítéséhez. Ebből a szempontból a teoretikus keret konzisztens.

Schlett műve elsőként hozza magával a korszak saját értelmezését egy olyan nézőpontból, 
amelynek hatásai a történelem későbbi eseményeiben is éreztetik hatásukat. A szerző paradigmaváltozások szakaszaiban mutatta be a gondolkodást, a Deák-féle gyakorlati politizálás melletti elkötelezettséggel. A teoretikus és pragmatikus összefüggések és gondolatok bizonyítását Schlett István korai idézetek ismertetésével teszi meg. A kánon megalkotásának nehézségei politikai gondolkodás szempontok szerint azonban szembeötlik a mű koherenciájának ellenére (Bodnár-Király, 2012:25). A heideggeri destrukciót teljesen maga mögött hagyva a dekonstrukció alapelveire épít, amely kivehető a liberalizmus-konzervativizmus oppozíciójában. Kossuth szenvedélyes lázítása került szembe Deák higgadt elvszerűségével (G. Fodor, 2012:6). Azonban az ilyen ellentétek a saját gondolkodásunkba is beépítik az ellentét tradícióit, ezáltal konzerválják a hagyományok egy részét biztosan, de kötelezettséget is nyernek a korszerüsítésre.

\section{JEGYZETEK}

1 HŐNICH HENRIK PhD, tudományos munkatárs, NKE Eötvös József Kutatóközpont, Molnár Tamás Kutatóintézet (Honich.Henrik@uni-nke.hu), NAGY ÁGOSTON, tudományos segédmunkatárs, NKE Eötvös József Kutatóközpont, Molnár Tamás Kutatóintézet (Nagy.Agoston@uni-nke.hu), KOI GYULA PhD, tudományos főmunkatárs, NKE Államtudományi és Nemzetközi Tanulmányok Kar, Lőrincz Lajos Közigazgatási Jogi Tanszék (Koi.Gyula@uni-nke.hu), SÁFRÁN JÓZSEF, tudományos segédmunkatárs, NKE Államtudományi és Nemzetközi Tanulmányok Kar, Lőrincz Lajos Közigazgatási Jogi Tanszék (Safran.Jozsef@uni-nke.hu).

2 A Schlett István pályaképe címủ rész Koi Gyula; A hazai politika gondolkodás története a gentilizmus korától 1848-ig című rész Hônich Henrik és Nagy Ágoston; A hazai politika gondolkodás története az 1848-as forradalomtól 1900-ig című rész Sáfrán József munkája.

3 Az 1970-es években az alábbi személyek voltak az ELTE ÁJK Tudományos Szocializmus Tanszék óraaadó oktatói, „külsős,” vagy másodállásban foglalkoztatott tanárai: Boros Zsuzsanna, Bőhm Antal, Gombár Csaba, Kolosi Tamás, Papp Zsolt, Szabó Dániel, Szobolevszki Sándor, később Széll János. Demonstrátorok vagy a tanszéki diákkörhöz kötődő hallgatók voltak: Csillag István, Forgács Imre, Lengyel László, és mások (Bihari, 1999:8).

4 Megjegyzendő, hogy a paradigma fogalmát egészen más értelemben használja például John G. A. Pocock, aki azt a politikai nyelvekre vonatkoztatva éppenséggel azt hangsúlyozza, hogy mivel a politikai diskurzus természetéből adódóan és alapvetően „poliglott”, a politikai nyelvek paradigmaként való értelmezése nem lehet egyenértékű egy olyan modellel, amelyben egy bizonyos politikai nyelv más nyelveket kiszorítva egyeduralkodó szerepre tehet szert (Pocock, 1987:21).

\section{FELHASZNÁLt IRODALOM}

Bihari Mihály (1999): Köszöntő. In: Bihari Mihály - Cieger András (szerk.): „Képzeljetek embert.” Politikaelméleti tanulmányok Schlett István 60. születésnapjára. Barátaitól, pályatársaitól, tanítuányaitól. Korona Kiadó - ELTE ÁJK Politológia Tanszék. 7-9.

Bodnár-Király Tibor - Nagy Ágoston (2008): Egy különös eszmetörténeti kiméra. (Takács József: Modern magyar politikai eszmetörténet). Politikatudományi Szzmle, 17. évf., 4. sz., 183-191.

Bodnár-Király Tibor (2012): Adalékok A politikai gondolkodás története Magyarországon I-II. Szekfü-oltványaihoz. Századvég, 17. évf., 64. sz., 25-39.

Elek Péter - Gunda Béla - Hilscher Zoltán- Horváth Sándor - Karsay Gyula - Kerényi György Koczogh Ákos Kovács Imre - Pócsy Ferenc - Torbágyi László (1936): Elsüllyedt falu a Dunántúlon. Kemse község élete (szerk.: gr. Teleki Pál). Sylvester Irodalmi és Nyomdai Intézet Rt. - Pro Christo Diákok Háza Falukutató Munkaközösség.

G. Fodor Gábor (2012): Schlett mủhelyében. Paula Schultz ismeretlen sírhelye. Századvég, 17. évf., 64. sz., 3-6.

Horváth Zsófia (2018): Schlett István: Az egyetemre politika nem való. 888.hu (2018.12.13.), https://888.hu/sza- 
Hönich Henrik - Koi Gyula - Nagy Ágoston - Sáfrán Fózsef: Meglátások Schlett István: ...

bad-vasarnap/schlett-istvan-az-egyetemre-a-politika-nem-valo-4164531/

Mándi Tibor (2015): Politikai gondolkodás. In: Körösényi András (szerk.): A magyar politikai rendszer-negyedszázad után. Osiris Kiadó, Budapest. 13-34.

Nagy Ágoston (2012): „A politikai gondolkodás történetének” kontextualista-konceptualista dimenziói. Századvég, 17. évf., 64. sz., 40-62.

Pocock, John G. A. (1987): The concept of a language and the métier d'historien: some considerations on practice. In: Pagden, Anthony (ed.): The Languages of Political Theory in Early Modern Europe. Cambridge University Press, Cambridge. 19-38.

Rácz Anna (2019): Születésnapi interjú Schlett István professor emeritussal. https://www.ajk.elte.hu/content/szuletesnapi-interju-schlett-istvan-professor-emeritussal.t.4771

Schlett István (1987): A „munkáskérdés” és a szocializmus a magyar politikai gondolkodásban 1848-1906. Adalékok a politikai ideológiák jelentésváltozásához. Kossuth Könyvkiadó, Budapest.

Schlett István (1993): Kisebbségnézóben. Kossuth Könyvkiadó, Budapest.

Schlett István (1996): A magyar politikai gondolkodás története I. Korona Kiadó, Budapest.

Schlett István (1999): A magyar politikai gondolkodás története II/1. A liberalizmus Magyarországon. Korona Kiadó, Budapest.

Schlett István (2004): A politikai gondolkodás története Magyarországon I. A kezdetektól a polgári átalakulásig. Rejtjel Kiadó, Budapest.

Schlett István (2009): A politikai gondolkodás története Magyarországon 1. Századvég Kiadó, Budapest.

Schlett István (2010): A politikai gondolkodás története Magyarországon 2. Századvég Kiadó, Budapest.

Schlett István (2018a): A politikai gondolkodás története Magyarországon 1. Századvég Kiadó, Budapest.

Schlett István (2018b): A politikai gondolkodás története Magyarországon 2. Századvég Kiadó, Budapest.

Schlett István (2018c): A politikai gondolkodás története Magyarországon 3. Századvég Kiadó, Budapest.

Schlett István (2018d): A politikai gondolkodás története Magyarországon. Appendix. Századvég Kiadó, Budapest. 